\title{
Accounting and Governance in Africa - Contributions and Opportunities for Further Research
}

\begin{tabular}{|r|l|}
\hline Journal: & Journal of Accounting in Emerging Economies \\
\hline Manuscript ID & JAEE-10-2017-0101 \\
\hline Manuscript Type: & Editorial \\
\hline & \\
\end{tabular}




\section{Accounting and Governance in Africa - Contributions and Opportunities for Further Research}

Teerooven Soobaroyen

Essex Business School, University of Essex, UK.

Mathew Tsamenyi

China Europe International Business School (CEIBS), Ghana.

Haresh Sapra

School of Business, University of Chicago Booth, USA.

\section{Abstract}

Purpose: This paper reviews and reflects on the contributions of the Journal of Accounting in Emerging Economies' special issue on accounting and governance in Africa.

Design/methodology/approach: The themes and contributions from the accepted papers are identified and discussed in relation to prior research and potential for further studies.

Findings: Key aspects of boards and corporate governance, audit reporting and quality and government accounting practices are revealed as mechanisms which, in some cases, did have some consequences in the African context. However, in other cases, accounting or governance mechanisms appear to be at the periphery of organisational practice and exhibit little influence on decision making and accountability.

Limitations and implications: Whilst this paper does not provide a systematic review of the literature in the African context, it provides relating to special issue's contributions on corporate governance, audit and government accounting on the continent.

Originality/value: This special issue extends the burgeoning scholarship in African accounting and governance and provides directions and opportunities for future research.

Keywords: accounting; governance; Africa.

\section{Introduction}

The role and consequences of accounting and governance practices in emerging economies continue to attract significant attention from researchers, policy-makers, and practitioners. Specifically, this attention relates to how such practices can contribute to the success of businesses, governments and societies in general. Over the past two decades, a number of African countries have implemented economic and political reforms mostly engineered by the international financial community, i.e. the World Bank and the IMF. While some of these reforms have been successful, others have largely failed. Thus, while successful countries have witnessed stable democratic political system and economic development, others still face challenges, including conflict, deficiencies in healthcare and educational systems, fragile or marginalized civil societies, weak governments, a lack of effective political leadership, corruption, and limited markets and private sector development. Paradoxically, many African countries have significant resources but continue to meet difficulties in leveraging these resources for the benefit of the people. Many of these countries also continue to be tied to donor programs but it is clear that these donor led reforms are largely not working due to a number of factors including the manner in which these reforms are initiated and implemented, weak institutions and the lack of political will in these countries. The failure of Western models and the emergence of countries such as China, India and 
Brazil have led more and more African countries to look at alternative models of development and to search for new economic partnerships.

In the clamor of the debate about Africa's transformation or lack thereof, the state of governance and accounting on the continent is often decried. Indeed, this has started to receive some attention in the empirical literature as demonstrated by recent works, reviews, and special issues from highly related disciplines or journals - public sector accounting (Goddard et al., 2015; Jayasinghe et al., 2015; Gaspar \& Mkasiwa, 2015; van Helden and Uddin, 2016), management accounting and control (Hopper et al., 2009), financial accounting, disclosure and governance (Tauringana and Mangena, 2012; Soobaroyen \& Ntim, 2013; Ntim, 2016; Mahadeo and Soobaroyen, 2016), and accounting, auditing and accountability in Africa (Nyamori et al., 2017). Notwithstanding, a lot more research needs to be done concerning the role of accounting and governance practices in Africa, as the extant literature appears skewed towards the larger and more vibrant African economies (e.g. Ghana, Nigeria, and South Africa) and the Anglophone context for that matter (Lassou and Hopper, 2015).

As a result, this special issue by the Journal of Accounting in Emerging Economies (JAEE) constitutes a part of the efforts to address the dearth of research in this area. Specifically, it focuses on accounting and governance practices in Africa. In all, five papers have been accepted for this issue, and have been grouped under three broad headings: (a) boards and corporate governance; (b) audit reporting; and (c) government accounting.

\section{A) Boards and corporate governance}

Many countries have adopted corporate governance (CG) codes alongside International Financial Reporting Standards (IFRS) with the aim to control ethical lapses as well as improve the reliability of financial information. However, extant findings show that whether codes achieve their objectives or not remains mixed and inconsistent, thereby making it difficult to generalize (Garcia-Meca, \& SanchezBallesta, 2009; Kaaya, 2015). One dimension of the CG debate which has started to receive attention in the African context is the association between CG and earnings management (EM). For example, the work of Akyeampong, Amidu \& Abor (2013) examined the nexus between CG and EM in selected SubSaharan African countries and reported varying results; leading them to conclude that the effects of CG mechanisms on EM are not the same across countries. But it would seem that they used only partial indicators for CG in their study. Therefore, Outa et al.'s paper in this special issue contributes to the debate by computing and using a composite CG indicator to examine the effect of CG codes on EM for listed non-finance firms in Kenya. They show that voluntary CG codes are not effective in constraining (EM) and highlight the problem that such codes are often not complied with or are not enforced by regulatory agencies. These cross-sectional results chime with recent interview evidence gathered from the Zambian context (Chanda et al., 2017).

Another dimension of the CG debate relates to the effect of board experience and independence in mitigating agency conflict between shareholders and managers. The agency theory posits that one important role of boards is to monitor managers to realign their interest to that of shareholders (Fleischer et al. 1988). Thus, while considering the board's motivation to monitor, the theory is less concerned about the board's ability to monitor. Resource dependency theory, however, does look at the need to develop linkages between the firm and outside resources such that there are influences in the appointment of directors with relevant skills, competencies and social capital to the firm (Nahapiet and Ghoshal, 1998). Given the apparent complementarity between the two theories, some studies have sought to integrate them to examine the impact of board experience and independence on agency conflict in mostly developed economies with more robust governance structures, albeit with inconclusive and fragmented outcomes (Johnson et al. 2012; Dalziel et al. 2011; Tian et al. 2011; Hillman 
et al. 2002). Given this and the apparent lack of studies in the African context, Agyemang Badu et al. investigates the impact of board experience and independence on mitigating agency conflict between shareholders and managers from an agency and a resource dependence perspective. They studied 137 listed firms from Ghana and Nigeria, and report a statistically negative relationship between board experience, board independence, and agency conflict. This may suggest that, in making appointments to boards, independence should be considered alongside experience to effectively deal with the issue of agency conflict. In formulating implications, both studies highlight the somewhat 'peripheral' nature of Western-led CG codes in that the intended reforms may in fact be too limited in the African context to generate substantive effects; instead incentivizing symbolic forms of compliance (Soobaroyen and Mahadeo, 2016). Thus, the call by Outa et al. to consider 'radical' change and thinking beyond traditional models is timely. For example, one might question how a strict approach to the definition of board 'independence' translates in the African environment and how this can (paradoxically) impede the board's ability to oversee management?

\section{B) Audit Reporting \& Quality}

In spite of the many criticisms faced by the audit profession post financial crisis, external audit remains one of the important external governance mechanisms in ensuring the reliability of financial information. Notably, it reduces the level of information asymmetry between the principal and agent (Boolaky and Quick, 2016). An unqualified audit opinion may be an indication of reassurance for users of financial information, whereas a modified audit opinion may well adversely affect the investor's confidence in financial information. The financial crisis of 2008 and its associated bankruptcy of companies in the developed world brought into question the reliability of financial statements as well as the independence of auditors. Following this, a number of studies have examined modifications issued in the case of financially stressed companies in developed economies (e.g. Svanberg and Ohman, 2014; Wu et al., 2016). The apparent lack of similar studies in developing or emerging economies has received a response in this special issue by Hanen. The work of Hanen investigates the effect of financial variables (profitability, loss, leverage, and liquidity) on audit report qualifications (qualified audit opinion) and audit report modifications (qualified audit opinion or unqualified but with an explanatory paragraph) during a period of financial and political crisis in Tunisia. As the author found, liquidity and loss in the current and previous year were associated with audit report qualification (qualified opinion) whereas leverage was associated with audit report modification. Interestingly, audit qualifications in the period of financial crisis were shown to have decreased quite significantly.

Nnadi et al's paper, also in this special issue, examines the effect of board structure, ownership structure and debt level on the demand of better external audit quality of firms in Morocco. Their work demonstrates a positive association between the demand for audit quality and the proportion of independent directors whereas the level of indebtedness had no effect on the demand for a better external audit. However, there was some association between the control exercised by independent directors and the demand for external audit quality. In conclusion, both studies address the significant gaps in knowledge about audit practice in Africa and of its determinants. However, much remains to be done to ascertain the process of external audit in Africa, in the context of a continuing dominance of firms that are branches of, or affiliated to, Big 4 firms; the various shades of audit regulation (e.g. selfregulation vs. state regulation) prevailing in the different countries.

\section{C) Government Accounting}

Accounting is seen an important tool which can be used by various governments to deliver effective resource management, transparency, and accountability, which collectively work to bring about economic development. One of its critical functions is the generation of relevant information that aids 
decision-making, planning, and control which are necessary for the attainment of development goals (Hopper et al., 2012). Despite its importance for development, the adopted government accounting reforms in Africa tend to be markedly different from what is actually practiced (Andrews, 2013); a phenomenon that has been theorized as a form of decoupling (Rautiainen and Järvenpää, 2012; Yapa, 2014). While few studies have looked at decoupling in government accounting in the African context, (e.g. Andrews, 2010, 2013; Lassou and Hopper, 2016), there I are some unresolved issues. For example, how and why do reforms decouple in different contexts such as the African Anglophone and Francophone countries which possess varied government accounting provisions and traditions?

Lassou's paper in this special issue addresses these issues. He uses the lenses of patrimonial systems (Hopper, 2016) and organizational façades (Cho et al., 2015) to investigate government accounting practices in Ghana and Benin and concluded that the adopted government accounting reforms for the two countries are different from what is actually implemented. This is attributed to indigenous neopatrimonial governance traits of informal institutions, patronage and clientelism. Further, although the Ghanaian government accounting system was found to be functionally superior to that of the Beninese case, its implementation still tended to be rather symbolic in nature and not contributing to better decision making. Given the primacy of the state in many African nations and its often direct involvement in the commercial and business arena, the extent of published work on governance and accounting is in Africa woefully limited and deserves much more and urgent attention.

\section{Conclusion}

On the basis of the empirical studies published in this special issue, we conclude that the authors have addressed some noteworthy issues and made a modest contribution to our understanding of accounting and governance practices in the context of Africa. However, this is just the beginning. A lot more work will have to be done to significantly extend the literature in this area, particularly in consideration of a variety of national and organisational settings. Most of the selected studies also relied on quantitative and positivist approaches. Whilst they do report interesting findings, they could not capture in great detail 'why' the phenomenon exists or 'how' the phenomenon takes place. As a result, these studies raise many more questions about the state of accounting and governance. We suggest that a qualitative approach using in-depth interviews and archival methods may be helpful in addressing the 'why' and 'how' questions of accounting and governance practices in Africa. Further studies also need to ascertain and use new proxies to investigate issues of accounting and governance practices in African countries outside of those reported here. There is also often a reliance on explanatory variables drawn from research and agency theory-based models carried out in developed countries but the coverage of similar data (and availability of databases) in Africa is problematic, resulting in a crucial issue of low sample size, albeit that there have been some improvements for particular countries. There is, therefore, a compelling case for the development of more extensive databases of African companies and entities and in parallel, a need for greater engagement with qualitative research approaches and theoretical perspectives which can illuminate and better explain accounting and governance practice in Africa.

We wish to thank all the contributors to this special issue for submitting high quality papers. Also, we would like to thank the reviewers who made time to critically evaluate the selected papers through the several rounds of reviews. We single out the efforts of the African Accounting and Finance Association (AAFA) in its recent efforts to build research across Africa and for supporting/disseminating the call. Finally we hope the readers will share our joy, and find this special issue very useful in their understanding of African accounting and governance. 


\section{References:}

Andrews, M. (2013). The limits of institutional reform in development - Changing the rules for realistic solutions, New York, Cambridge University Press.

Andrews, M. (2010). How far have public financial management reforms come in Africa?, Working paper, Boston, John F. Kennedy School of Government.

Akyeampon, D., Amidu, M., \& Abor, J. (2013). Corporate Governance and Earnings Management: Evidence from Sub-Saharan Africa. Available at http://ugspace.ug.edu.gh/handle/123456789/4559. Accessed 5th Jan 2016.

Boolaky, P. K., \& Quick, R. (2016). Bank Directors' Perceptions of Expanded Auditor's Reports, International Journal of Auditing, 20, 158-174.

Cho, C. H., Laine, M., Roberts, R. W., \& Rodrigue, M. (2015). Organized hypocrisy, organizational facades and sustainability reporting. Accounting, Organizations and Society, 40 (1), 78-94.

Dalziel, T., Gentry, R. J., \& Bowerman, M. (2011). An Integrated Agency - Resource Dependence View of Directors' Human and Relational Capital on Firm's R\&D Spending. Journal of Management Studies. doi: 10.1111/j.1467-6486.2010.01003.

Garcia-Meca, E., \& Sanchez-Ballesta, J. (2009). Corporate Governance and Earnings Management: A Meta-Analysis. Corporate Governance: An International Review, 17 (5), $594-610$.

Gaspar, A. F., \& Mkasiwa, T. A. (2015). Managing performance or legitimacy? A case study of the Tanzanian Local Government Authorities. Journal of Accounting in Emerging Economies, 5(4), 424456.

Goddard, A., Assad, M., Issa, S., Malagila, J. \& Mkasiwa, T.A., (2015). The two publics and institutional theory - A study of public sector accounting in Tanzania. Critical Perspectives on Accounting. doi.org/10.1016/j.cpa.2015.02.002

Hillman, A. J., Cannella, A. A., Jr. and Harris, I. C. (2002). Women and racial minorities in the boardroom: How do directors differ? Journal of Management, 28(6), 747-763.

Hopper, T., Tsamenyi, M., Uddin, S., \& Wickramasinghe, D. (2009). Management Accounting in Less Developed Countries: What Is Known and Needs Knowing. Accounting, Auditing \& Accountability Journal, 22(3), 469-514.

Hopper, T., Tsamenyi, M., Uddin, S., \& Wickramasinghe, D. (Eds) (2012). Handbook of Accounting and Development, Cheltenham, Edward Elgar Publishing.

Hopper, T. (2016). Neopatrimonialism, Good Governance, Corruption and Accounting in Africa: Idealism versus Pragmatism. Journal of Accounting in Emerging Economies (in press)

Jayasinghe, K., Nath, N.D. \& Tauringana, V. and Othman, R. (2015) (eds). Public Sector Accounting, Accountability and Auditing in Emerging Economies. Research in Accounting in Emerging Economies. Vol. 15. Emerald.

Kaaya, D. (2015). The Impact of International Financial Reporting Standards (IFRS) on Earnings Management: A Review of Empirical Evidence. Journal of Finance and Accounting, 3(3), 57-65.

Lassou, P. J. C., \& Hopper, T. (2015). Government accounting reform in an ex-French African colony: The political economy of neocolonialism. Critical Perspectives on Accounting. doi.org/10.1016/j.cpa.2015.10.006.

Mahadeo, J.D. \& Soobaroyen, T., (2016). A longitudinal study of the implementation of the corporate governance code in a developing country: The case of Mauritius. Business \& Society, 55(5), 738-777.

Nahapiet, Y. \& Ghoshal, S. (1998) Social Capital, Intellectual Capital, and the Organizational Advantage. The Academy of Management Review, 23(2), 242-266.

Ntim, C. G (2016). Corporate Governance, Corporate Health Accounting and Firm Value: The Case of HIV/AIDS Disclosures in Sub-Saharan Africa. International Journal of Accounting. Forthcoming. 
Nyamori, R.O., Abdul-Rahaman, A.S., \& Samkin, G., 2017. Accounting, auditing and accountability research in Africa: Recent governance developments and future directions. Accounting, Auditing \& Accountability Journal, 30(6), 1206-1229.

Rautiainen, A., \& Järvenpää,M., (2012). Institutional Logics and Responses to Performance Measurement Systems. Financial Accountability \& Management, 28(2), 164 - 188.

Soobaroyen, T., \& Ntim, C. G. (2013). Social and environmental accounting as symbolic and substantive means of legitimation: The case of HIV/AIDS reporting in South Africa. Accounting Forum, 37(2), 92109.

Savanberg, J. \& Öhman, P. (2014). Lost revenues associated with going-concern modified opinions in the Swedish audit market. Journal of Applied Accounting Research, 15(2), 197-214.

Tauringana, V., \& Mangena, M. (2012) (eds). Research in Accounting in Africa. Research in Accounting in Emerging Economies. 12A. Emerald.

Tian, J., \& Haleblian, N.R. (2011). The effect of board human and social capital on investor reactions to new CEO selection. Strategic Management Journal, 32, $731-747$

Van Helden, J., \& Uddin, S. (2016). Public sector management accounting in emerging economies: A literature review. Critical Perspectives on Accounting, 41, 34-62.

Wu, C. Y., Hsu, H., \& Haslam, J. (2016). Audit committees, non-audit services, and auditor reporting decisions prior to failure. The British Accounting Review, 48, 1-17. 